\title{
Subsoil Engineering Characterization and Foundation Design in Derived Geological Coastal Sands of Ilaje Area of Ondo State, Nigeria
}

\author{
Falowo O. Olumuyiwa*, Otuaga M. Philip \\ Department of Civil Engineering Technology, Faculty of Engineering Technology, Rufus Giwa \\ Polytechnic, Owo, Ondo State, Nigeria. oluwanifemi.adeboye@yahoo.com
}

Abstract Engineering subsoil evaluation and foundation design have been undertaken at Ilaje area of Ondo State, Nigeria. The aim of this study was to examine the geo-electrical and geotechnical parameters of the subsoil to sustain building structures and also provide appropriate foundation design alternatives. A total of six VES stations were occupied and complemented with geotechnical analysis of seven soil samples collected at two cone penetration test locations. The result showed that all the determined geotechnical parameters of the subsoil fall within the specification recommended for foundation material by federal ministry of works and housing of Nigeria. The VES showed a predominant $(66.67 \%)$ HKQ curve type. The upper $5 \mathrm{~m}$ is characterized by moderate thickness and high resistivity (average of $450 \mathrm{ohm}-\mathrm{m}$ ) values to sustain structural load. An average allowable bearing capacity of $150 \mathrm{KN} / \mathrm{m}^{2}$ was recommended for design of bases/footings for shallow foundation at a depth not less than $1.0 \mathrm{~m}$. The obtained settlement values are less than $50 \mathrm{~mm}$ and within tolerable limit, for foundation width ranging from 0.5 to $3.0 \mathrm{~m}$. However there was drastic reduction in settlement values (below 25mm) when the foundation width was increased to 2 and 3m. The allowable capacity of the driven pile ranges from $64-115 \mathrm{KN}, 206-347 \mathrm{KN}$, and $418-677 \mathrm{KN}$ at $5 \mathrm{~m}, 10$ $\mathrm{m}$ and $15 \mathrm{~m}$ respectively. The allowable bearing capacity for bored piles ranges from $34-69 \mathrm{KN}, 85-165 \mathrm{KN}$, and 146 -268 at depth levels of $5 \mathrm{~m}, 10 \mathrm{~m}$, and $15 \mathrm{~m}$ respectively.

Keywords - CPT, Ilaje, square and strip footing, structural load, bearing capacity, vertical electrical sounding

\section{INTRODUCTION}

The stability of engineering structures depends on the support offered by the foundation materials that bear the load of the structure [1]. The ability of foundation materials to offer necessary bearing support for engineering structures depend on the bearing capacity of the soil and/or rock [2]. Geological and structural factors such as mineralogical composition, rock fabric, rock association, degree of weathering, fluid saturation, rock deformation and occurrence of joints and faults would not only define the bearing strength of the foundation rocks, it could also impact spatial variability in the strength of the foundation material arising from heterogeneity in rock's physical properties [3]. In recent times, there has been a spate of building distresses and/or collapse in some areas in Ilaje, Ondo State. This failure could be investigated to be as a result of faulty foundation design. This motivated the researcher to carry an in-situ test in the area to ascertain the competence of the subsurface geology to host structures and possibly provides design alternatives to intending builders and engineers in the area. The pre-construction investigation may involve direct mechanical boring, pitting and trenching for subsoil sequence delineation, groundwater table mapping, soil sampling, and geotechnical analysis. It may also involve non-invasive geophysical investigation. The use of cone penetrometer test (CPT) and standard penetration test (SPT) have become increasingly useful in subsurface engineering study to obtain information about physical and engineering properties of the subsoil which may include strength and competence of the material that make up the subsoil materials.

Cone penetration test (CPT) is considered the most frequently used method for characterization of geomedia. The CPT is basically advancing a cylindrical rod with a cone tip into the soil and measuring the tip resistance and sleeve friction due to this intrusion [4]. The resistance parameters are used to classify soil strata and to estimate strength and deformation characteristics of soils. Different devices added to cone penetrometers made it possible to apply this test for a wide range of geotechnical applications. The CPT is a simple, quick, and economical test that provides reliable in situ continuous soundings of subsurface 
soil. Due to the alluvial nature of soil deposits in Ilaje, CPT is considered as a perfect tool for the site characterization. The application of cone penetration test, CPT has been increased in foundation engineering due to supplying continuous and accurate soil profile in recent years. A static analytical model based on general shear failure mechanism of logarithm spiral has been developed for calculating directly bearing capacity of footings $\left(\mathrm{q}_{\mathrm{ult}}\right)$ from cone resistance $q_{c}$ [5]. One of the main step for safe and economic design of foundations is ultimate bearing capacity determination. The maximum load that can be applied to subgrade soil from foundation with no occurrence of shear failure and limiting settlement in an allowable upper bond to avoid serviceability damages of superstructure. Four approaches currently are used to determine the bearing capacity of shallow and deep foundations; static analysis, in-situ testing methods, full-scale loading tests and using presumed values recommended by codes and handbooks. Among these approaches, theoretical solution (static analysis) is more common and applied first [6].

The advantages of CPT in contrast to other common in-situ tests is that, it's simple, fast, relatively economical, and it supplies continuous records with depth. The results are interpretable on both empirical and analytical basis, and a variety of sensors can be incorporated with cone penetrometer. Evaluating bearing capacity from CPT data is one of the earliest applications of this sounding and includes two main approaches: direct and indirect methods [7-8]. Direct CPT methods apply the measured values of cone bearing for toe resistance with some modifications regarding scale effects (influence of foundation width to the cone diameter ratio). Indirect CPT methods employ friction angle and undrained shear strength values estimated from CPT data based on bearing capacity and/or cavity expansion theories. The present study/research is aimed at determining important geotechnical parameters that are valuable for foundation design and infrastructural development.

However, supplementing the in-situ cone penetrometer with geophysical investigation will give adequate knowledge of the engineering properties of the subsoil materials that would have direct interaction with the proposed structure. For geophysical studies, electrical resistivity method is the most common technique used for such purpose [9-12]. Electrical resistivity technique of geophysical investigation is an effective tool in delineating subsurface layers and to reliably identify underground structures [13]. This is because the method is reliable, efficient and cost effective. Information such as thickness from vertical electrical sounding (VES) and CPT are some of the commonly applied geophysical and geo-engineering techniques in foundation studies. Authors [14], [15] and [16] have successfully employed VES and CPT in subsurface investigation for engineering purposes. Hence, this study was focused on the characterization of subsurface for foundation studies using VES and CPT techniques at Ilaje coastal environment of Ondo State, Nigeria.

\section{RESEARCH METHOD}

\section{A. Study Area}

The study area is Ilaje local government area of Ondo State, which falls within southwestern Nigeria (Figure 1) between 670000 and $740000 \mathrm{mE}$ and 630000 and $720000 \mathrm{mN}$. Major part of the study area is devoted to fishing activities. Also oil exploration and exploitation are presently carried out onshore in the study area. The people of the area depends on government boreholes and streams for drinking and other domestic uses. The area is within the tropical rain forest region of Nigeria characterized by wet and dry seasonal variations, with a mean annual rainfall of $180 \mathrm{~cm}$, mean temperature of $24{ }^{\circ} \mathrm{C}$, and mean humidity of $80 \%$ [17]. The study area is generally characterized by flat and gently undulating topography. Topographic elevations vary from about 2 to $10 \mathrm{~m}$ above sea level. The area is drained by many perennial streams and rivers such as Ominla, Akeun, Ufara, Okomu, Ofara and others, which form a network of dendritic drainage pattern and empty their waters into the Atlantic Ocean to the south [18]. The rivers and streams in the area are being fed by several lagoons, ponds, canals, creeks and small streams scattered across the study area. There are major and minor rivers in the area. The major rivers include rivers Oluwa and Siluko. Others include Oloto, Salawa and Erifa, Iju-Osun, Otu Rivers [19]. The Atlantic Ocean terminates the Ilaje end of the study area. The elevation the area and closeness to the sea make the study area prone to flooding/sea water incursion which normally threatened integrity of foundation especially shallow foundation. In places where pile foundation is used, they are usually constructed by timber of soft woods which could easily undergo serious tension/compression under loading (Figure 2).

The area is characterized by heavy annual rainfall averaging about 2,000 $\mathrm{mm}$. Rainfall is distributed virtually over all the months of the year with the minima occurring between November and March. Plant type is generally mangrove in the costal part of the study area, typical of swamp forest, while the mainland area is characterized by oil palm, rubber plantation and other broadleaved species, typical of rainforest vegetation. The different ethnic groups that live in the area are the Egbados, Ikales, Ilajes and Ijaws. They live in hamlets, villages and towns which are closely separated from each other although mostly connected by fairly-good to poor roads.

The eastern Dahomey basin, geologically where the study area located, as beginning with the Abeokuta Group [20], made up of three Formations from oldest to the youngest namely; the Ise, Afowo and Araromi Formations (Figures 3 
and 4). The Ise Formation unconformably overlies the basement complex of southwestern Nigeria and consists of conglomerates and grits at base and in turn overlain by coarse-to-medium grained sands with interbedded Kaolinite. The conglomerates are unimbricated and at some locations ironstones occur [21]. The age is Neocomian to Albian. Overlying the Ise Formation is the Afowo Formation, which composed of coarse to medium grained sandstones with variable but thick interbedded shales, siltstones and claystones. The sandy facies are tar-bearing while the shales are organic-rich [22]. The lower part of this Formation is transitional with mixed brackish to marginal horizons that alternate with well sorted, sub-rounded sands indicating a littoral or estuarine near-shore environment of deposition. Using palynological assemblage, Billman [23] assigned a Turonian age to the lower part of this Formation, while the upper part ranges into the Maastritchian. Araromi Formation overlies the Afowo Formation (Figure 3) and has been described as the youngest cretaceous sediment in the eastern Dahomey basin [24]. It is composed of fine to medium grained sandstone at the base, overlain by shales, siltstone with interbedded limestone, marl and lignite. This Formation is highly fossiliferous containing abundant planktonic foraminifera, Ostracods, pollen and spores. Omatsola and Adegoke [24] assigned a maastritchian to palaeocence age to this Formation based on faunal content.

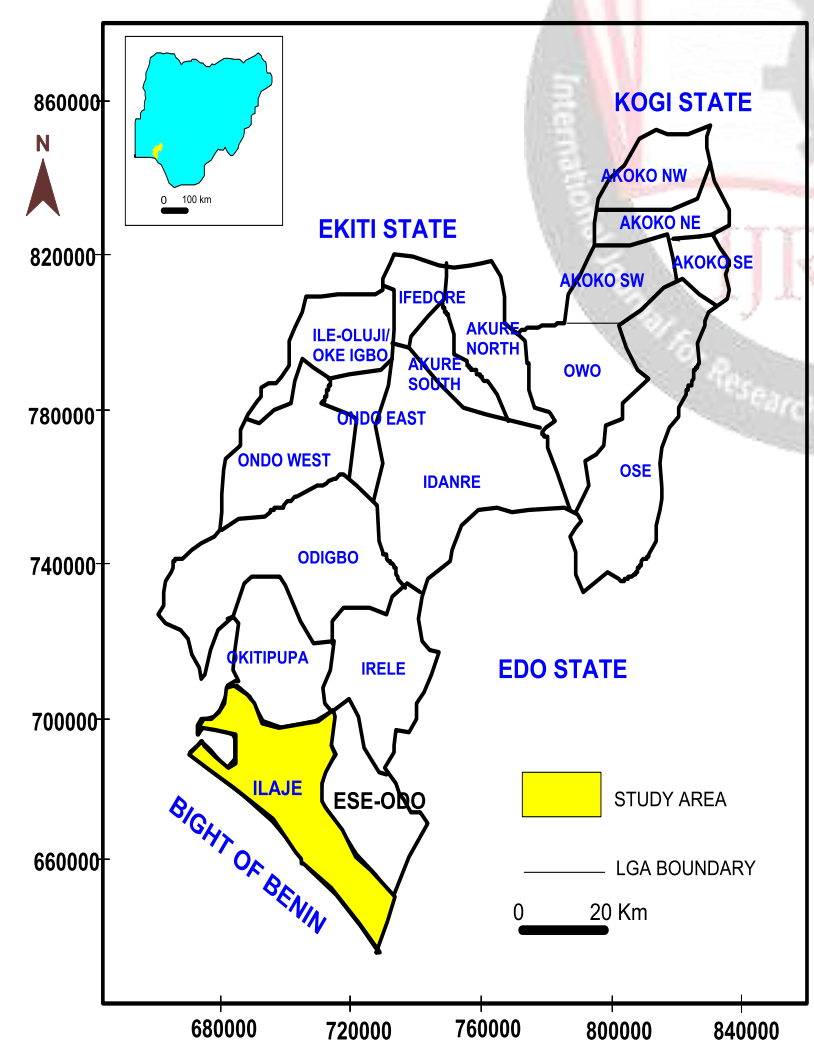

Figure 1: Location map of the Study Area

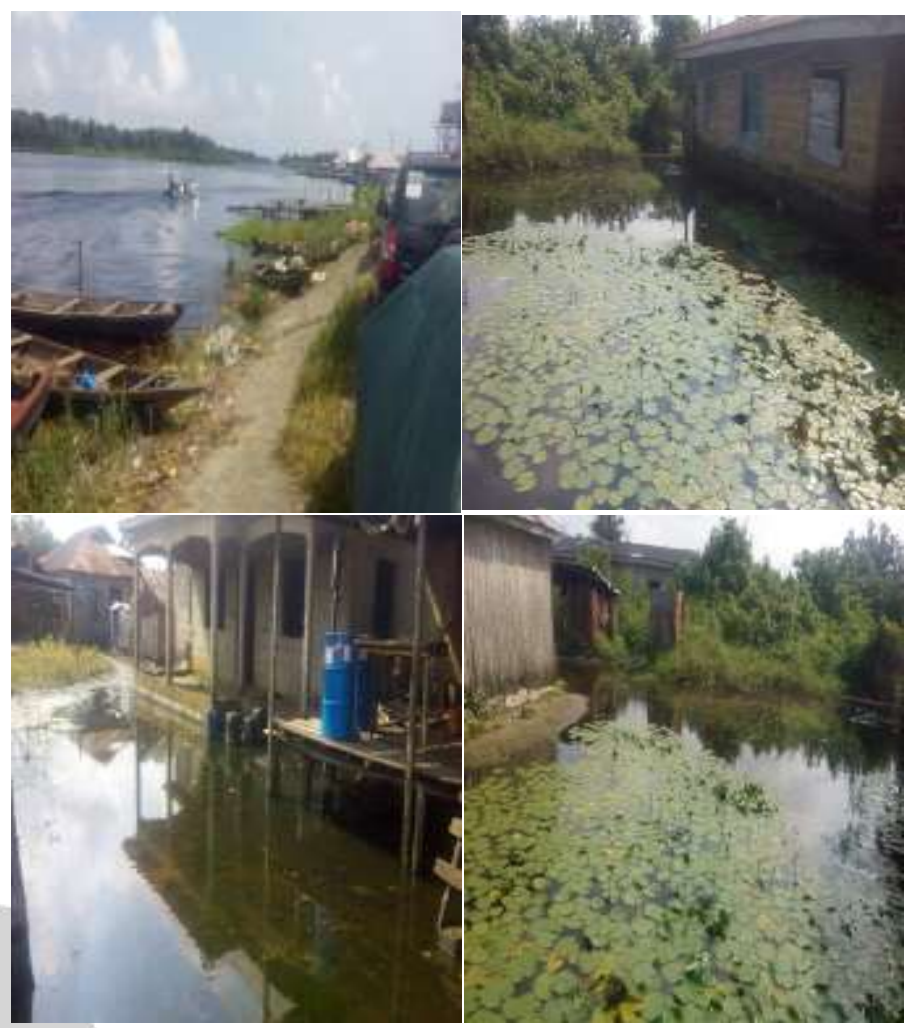

Figure 2: Diagram showing the closeness of the area to the Atlantic Ocean and how flooding is threatening the integrity of the foundation structures
$5^{0} \mathrm{E}$
$10^{\circ} \mathrm{E}$

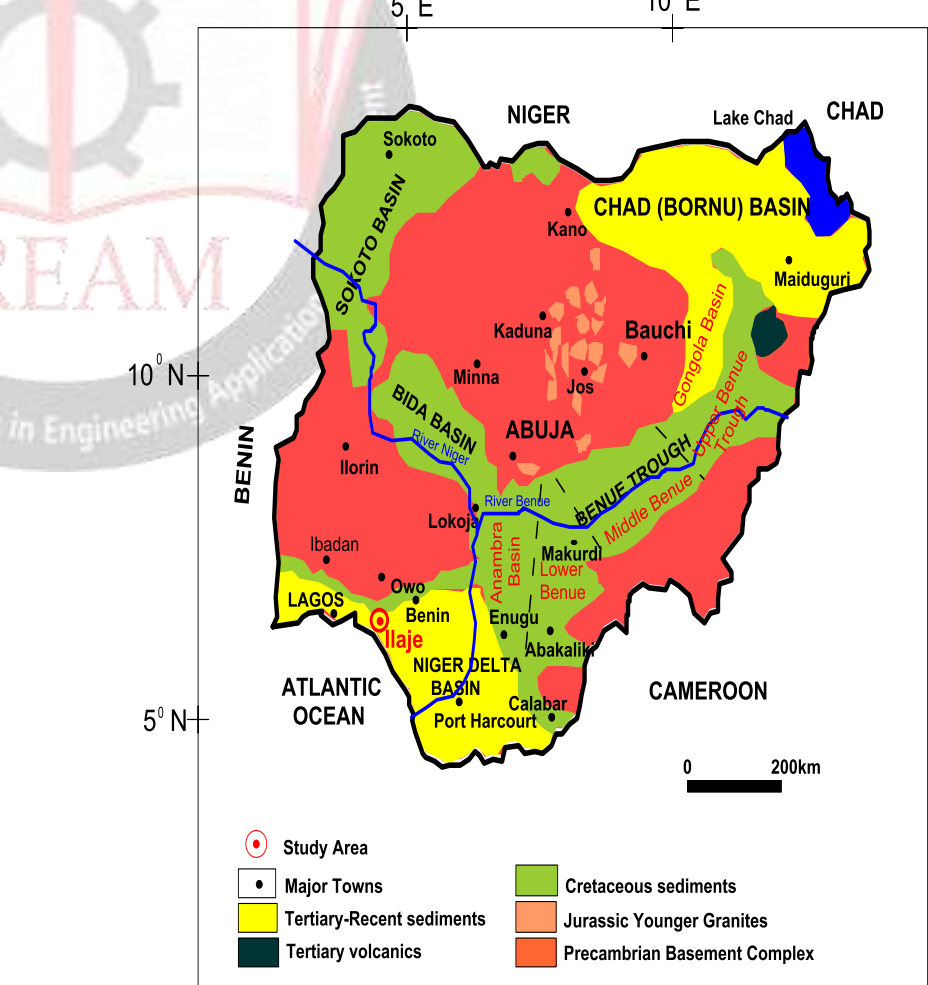

Figure 3: Geological map of Nigeria showing the Study Area on Tertiary - Recent sediments (Modified after Obaje [25]) 


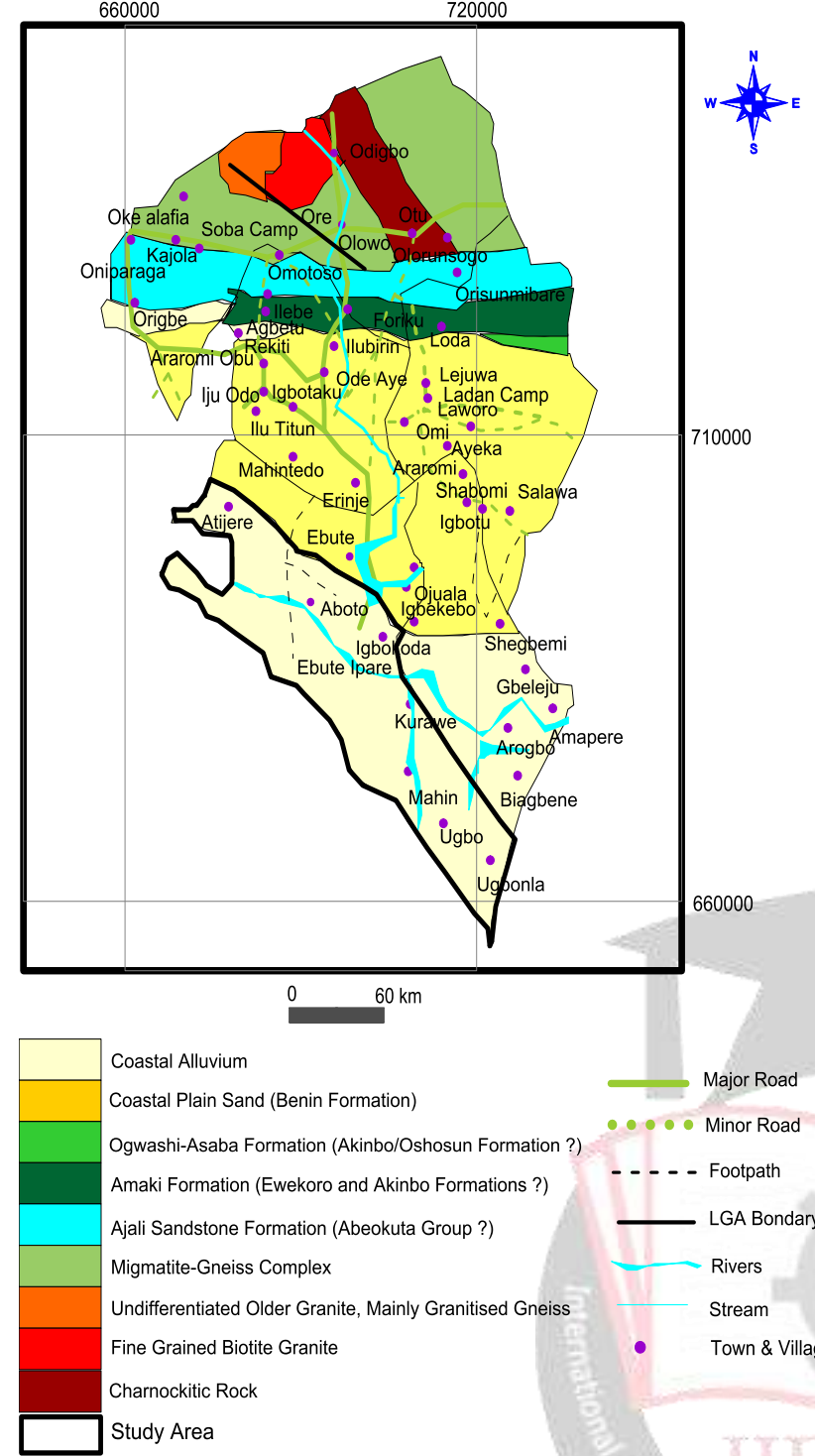

Figure 4: Local Geology map of the Area with predominant Alluvium sand

\section{B. Vertical Electrical Sounding (VES)}

The VES were acquired on the proposed site with Ohmega resistivity meter using Schlumberger array with maximum $\mathrm{AB} / 2$ of $750 \mathrm{~m}$. The geodetic coordinates of the locations were obtained using Garmin 72 Global Positioning System. A minimum of 2 and maximum of 4 stacks measurement were adopted to ensure high signal/noise ratio. Resist software was used to interpret the VES data. Two (02) parallel traverses trending approximately in the East - West direction were established in the study area (Figure 3). The established traverses length is $120 \mathrm{~m}$ each. Six (06) Vertical Electrical Sounding (VES) stations were occupied along these traverses using the Schlumberger electrode array (Figure 5). The distance between the VES points was $50 \mathrm{~m}$. The quantitative interpretation of the VES curves involved partial curve matching and computer assisted 1-D forward modelling with the RESIST software [26]. The VES interpretation results were used to generate geoelectric sections. Figure 4 shows the typical VES curves and the interpretation models.

\section{Cone Penetration Test (CPT)}

Cone Penetration Tests were performed at two (02) locations within the study area (Figures 5 and 6). CPT points were collocated with the VES locations (i.e. VES 2 and 4). The Dutch static penetration measures the resistance of penetration into soils using a $60 \%$ steel cone. The cone has an apex angle of $60^{\circ}$ and a base area of $10.2 \mathrm{~cm}^{2}$. The test was carried out by securing the winch frame to the ground by means of anchors which provided the necessary power to push the cone into the ground. The cone and the tube were pushed together into the ground for 20 to $25 \mathrm{~cm}$; the cone was pushed ahead of the tube for $20 \mathrm{~cm}$ at a uniform rate of about $2 \mathrm{~cm} / \mathrm{s}$. The resistance to the penetration of the cone registered on the pressure gauge connected to the pressure capsule was recorded. The tube was then pushed down and the procedure described above is repeated. Skin friction was not determined because small machine was employed in the investigation. This process was continued until the anchors start to lift out of the ground. Successive cone resistance readings were plotted against depth to form a resistance profile using Microsoft Office Excel 2007.
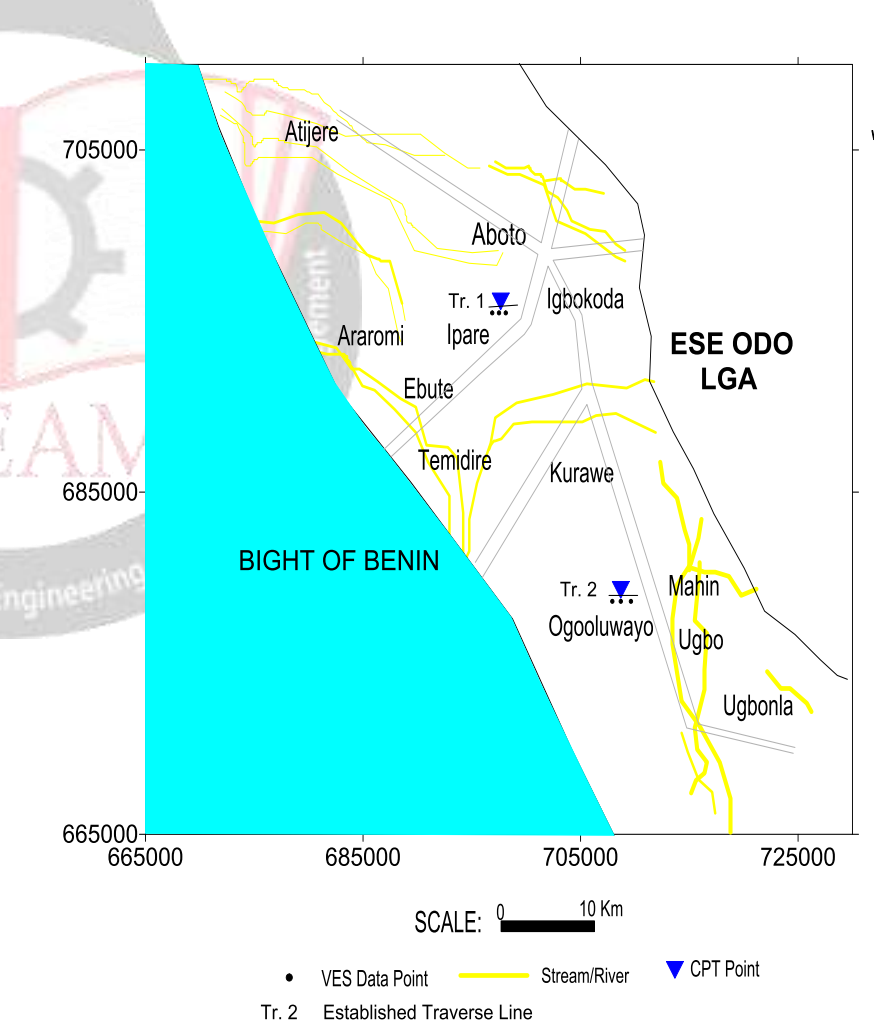

Figure 5: Data Acquisition Map

The layer sequences were interpreted from the variation of the values of the cone resistance with depth. The allowable bearing pressure of the soil layers on each location was calculated using Meyerhof [27] and Schmertmann [28] equation direct method for estimating ultimate bearing capacity $\left(\mathrm{q}_{\mathrm{ult}}\right)$ from cone resistance for square and strip footings. 


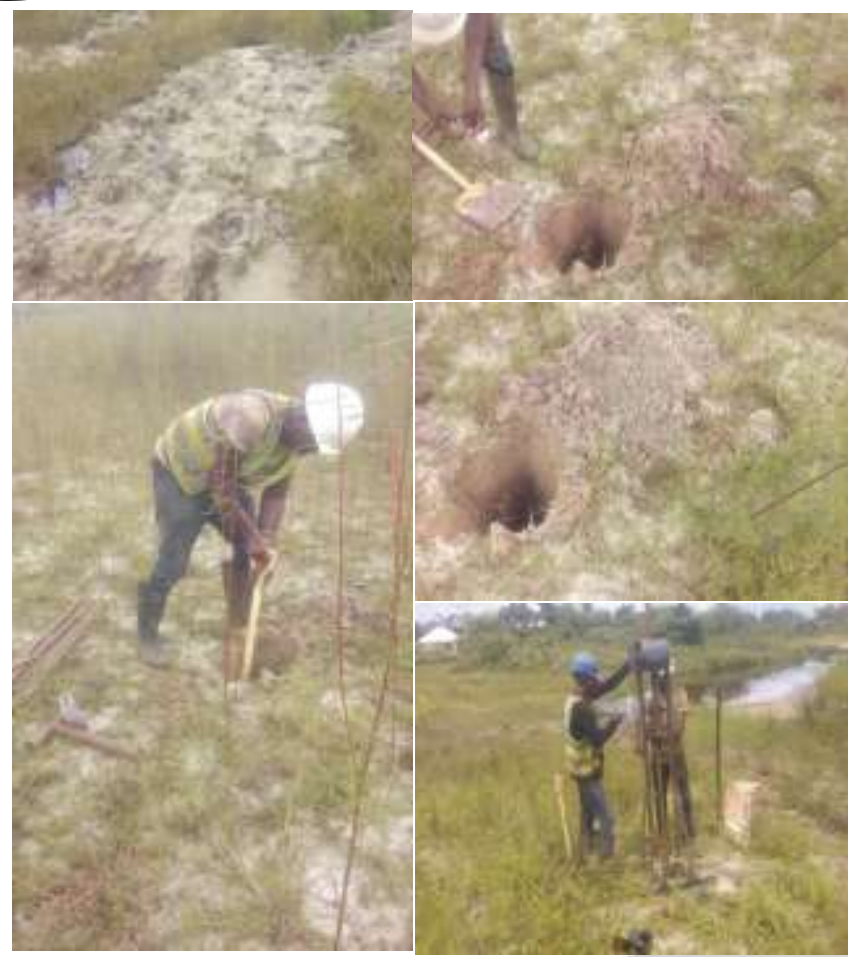

Figure 6: Field Pictures of in-situ CPT and Trial pits geotechnical tests

Factor of safety at least 3 is recommended by Meyerhof [27] to obtain the allowable bearing pressure.

For cohensionless soils:

Strip $q_{\text {ult }}=28-0.0052\left(300-q_{c}\right)^{1.5} \quad \mathrm{~kg} / \mathrm{cm}^{2}$ Square $q_{\text {ult }}=48-0.0052\left(300-q_{c}\right)^{1.5} \mathrm{~kg} / \mathrm{cm}^{2}$ For clay:

Strip $q_{\text {ult }}=2+0.28 \mathrm{q}_{\mathrm{c}}$

Square $q_{\text {uit }}=5+0.34 q_{c}$
$\mathrm{C}_{2}=$ secondary creep factor

$\mathrm{C}_{3}=$ shape factor

q' $=$ net bearing pressure

$\mathrm{I}_{\mathrm{e}}=$ strain influence factor

$\Delta z=$ thickness of soil layer (at midpoint of soil layer)

$\mathrm{E}_{\mathrm{s}}=$ equivalent modulus of elasticity

Empirical correction for depth of embedment, secondary creep, and footing shape:

$$
\begin{aligned}
& \mathrm{C}_{1}=1-0.5\left[\frac{\sigma_{\mathrm{xD}}^{y}}{q^{v}}\right] \\
& \mathrm{C}_{2}=1+0.2 \log (t / 0.1) \\
& \mathrm{C}_{3}=1.03-0.03{ }^{L} / \mathrm{B} \geq 0.73
\end{aligned}
$$

In order to use the Schmertmann [28], [30] method, it is necessary to estimate the stiffness of the soil in terms of equivalent Young's modulus at various depths. In the case of normally loaded cohensionless materials (not prestressed significantly to pressures above the present in in-situ overburden pressure, the CPT bearing capacity $\mathrm{q}_{\mathrm{c}}$ has been correlated with Young's modulus $\mathrm{E}_{\mathrm{s}}$ by DeBeer [31] and Webb [32]. The relationship suggested by Schmertmann $[30]$ is

$$
\mathrm{E}_{\mathrm{s}}=2 \mathrm{q}_{\mathrm{c}}
$$

where $\mathrm{q}_{\mathrm{c}}=$ CPT bearing capacity

Using Meyerhof [27] equation, the allowable and ultimate bearing capacity was calculated using this equation:

$$
\begin{aligned}
& q_{a}=2.7 q_{c}\left(\frac{K N}{\mathrm{~m}^{2}}\right) \\
& q_{a}=\frac{q_{c}}{40} \quad\left(\mathrm{~kg} / \mathrm{cm}^{2}\right)
\end{aligned}
$$

Subsequently a factor of safety of 3 was applied on the allowable bearing capacity to get the ultimate bearing capacity [33]. For this study CFEM [34] equation was used for modulus of elasticity determination. A modified version of the Terzaghi bearing capacity equation is widely used for pile design [35]. The third term, or the density term, in the Terzaghi bearing capacity equation is negligible in piles and hence usually ignored [36-37]. The lateral earth pressure coefficient, $\mathrm{K}$, is introduced to compute the skin friction of piles.

$P_{\text {witimate }}=\left(\sigma_{t}^{s} \times N_{q} \times A\right)+\left(K+\sigma_{v}^{s} \times \tan \delta \times A_{p}\right)$ where:

$\mathrm{P}_{\text {ultimate }}=$ ultimate pile capacity

$\sigma_{t}^{s}=$ effective stress at the tip of the pile

$\mathrm{N}_{\mathrm{q}}=$ bearing factor coefficient

$\mathrm{A}=$ cross sectional area of the pile at the tip

$\mathrm{K}$ = lateral earth pressure coefficient

$\sigma_{v}^{b}=$ effective stress at the perimeter of the pile

$\tan \delta=$ friction angle between pile and soil

$A_{p}=$ perimeter area of the pile

For round piles, $A_{p}=(\pi d L)$

where:

d - diameter

$\mathrm{L}=$ length of the pile

The American Petroleum Institute (API) method [38] uses the following equation for end bearing capacity, which was adopted for this study where

$$
q=N_{q} \times \sigma_{t}^{s} \times A
$$

$\mathrm{q}$ is end bearing capacity of the pile $\sigma_{t}^{x}$ is effective stress at pile tip 
$\mathrm{A}$ is cross sectional area of the (circular) pile at the tip $=$ $\pi \times \frac{D^{2}}{4} ; \mathrm{D}$ is the pile diameter

The maximum effective stress used in the computation is within the $240 \mathrm{kPa}$ recommended [39-40]. The value of $\mathrm{N}_{\mathrm{q}}$ depends on the soil:

$\mathrm{N}_{\mathrm{q}}=8$ to 12 for loose sand

$\mathrm{N}_{\mathrm{q}}=12$ to 40 for medium dense sand

$\mathrm{N}_{\mathrm{q}}=40$ for dense sand

Meyerhof [27] suggested the following equation for driven/bored piles:

$$
s=\beta \times \sigma_{v}^{s} \times A_{p}
$$

where

$\mathrm{s}=$ skin friction of the pile

$\sigma_{v}^{b}=$ effective stress at the midpoint of the pile

$A_{p}=$ perimeter surface area of the pile

$$
\begin{aligned}
\text { For driven piles } \beta & =0.44 \text { for } \varnothing=28^{\circ} \\
& =0.75 \text { for } \varnothing=35^{\circ} \\
& =1.2 \text { for } \varnothing=37^{\circ} \\
\text { For bored piles } \beta & =0.10 \text { for } \varnothing=33^{\circ} \\
& =0.20 \text { for } \varnothing=35^{\circ} \\
& =0.35 \text { for } \varnothing=37^{\circ}
\end{aligned}
$$

\section{RESULTS AND DISCUSSION}

The interpreted results were presented in the form of geoelectric section along the two traverses in Figures 7 and 8. The VES results showed four to five geoelectric layers across the study area but are distinguished into four major geological layers, comprising the topsoil, silty sand, surficial aquifer unit, and intermediate aquifer unit. Four (04) different curve types were delineated across the study area: HK, HKH, and HKQ. Curve types. The HKQ dominates the study area with frequency of 4 accounting for $66.67 \%$.

This geoelectric section along Traverse 1 in Igbokoda consist of alluvium sand topsoil, surficial aquifer and intermediate aquifer unit. The topsoil is characterized by resistivity ranging from 155 - $11213 \mathrm{ohm}-\mathrm{m}$ with thickness of $2.0-5.0 \mathrm{~m}$. The weathered layer (which is the surficial aquifer) has resistivity varying from $198-423 \mathrm{ohm}-\mathrm{m}$, with thickness of $68.2-122.4 \mathrm{~m}$. The intermediate aquifer underlies the surficial aquifer with resistivity in between 56 and $219 \mathrm{ohm}-\mathrm{m}$, and depth range to this geologic unit is in between 76.8 - $125.1 \mathrm{~m}$. Both the surficial and intermediate aquifer form the major aquifer system in the area. Consequently, the topsoil (the upper $5 \mathrm{~m}$ ) has high resistivity and thickness values that can sustain structural foundation load. The presence of groundwater in the soil pores has a very significant impact on the engineering behavior or characteristics of the soil, and very important where deep excavation are to be carried out. The groundwater level along this traverse measured during the CPT survey under VES 2 records value of $0.5 \mathrm{~m}$, which is believed to be connate water trapped during sedimentation / lithification process. This depth to this water level is within the targeted foundation depth of $5 \mathrm{~m}$ for shallow foundation design in the area. Consequently, this observation needs to be incorporated during the design process, as groundwater level may seriously affect the bases of the foundation footing along this traverse [41].

The geoelectric section along Traverse 2 in Ugbonla also showed four distinct subsurface layering, comprising the topsoil, silty sand, weathered layer (surficial aquifer) and intermediate aquifer unit. The topsoil is made of coastal white sand with resistivity varying from 411 - 111 ohm-m and thickness of $4.8-5.8 \mathrm{~m}$. The silty sand underlying the coastal sand has resistivity values varying from $448-612$ ohm-m, and thickness variation of 8.3 to $15.8 \mathrm{~m}$. The surficial sand aquifer unit is the most prolific aquiferous zone, which is the depth of most boreholes in the area, has layer resistivity ranging from 38 - $102 \mathrm{ohm}-\mathrm{m}$ and thickness of $72.1-95.2 \mathrm{~m}$. The intermediate aquifer has resistivity ranging from $56-92 \mathrm{ohm}-\mathrm{m}$. The depth to this aquifer unit is in between 86.1 and $116.8 \mathrm{~m}$. The low resistivity values recorded for these aquifer system could attributed to high degree of water saturation. The existing well and borehole under VES 4 and 5 record groundwater level of $12 \mathrm{~m}$ and $23 \mathrm{~m}$ respectively, with an average of $17.5 \mathrm{~m}$. This depth is far below the combined targeted foundation depth $\left(D_{f}\right)$ of $5 \mathrm{~m}$ and foundation width maximum of $5 \mathrm{~m}$ for shallow foundation design. This implies that the groundwater level may not or seriously affect the bases of the foundation footing along this area [41]. Hence the topsoil and silty sand material is moderately competent to harbor the foundation structure along this traverse.

The results of the CPT and laboratory analysis of samples collected during trial test/soil examination is presented in Tables 1 and 2. The result shows increase in cone resistance and sleeve resistance with depth, ranging from $15-88$ $\mathrm{kg} / \mathrm{cm}^{2}$ and $28-110 \mathrm{~kg} / \mathrm{cm}^{2}$ at CPT 1 , and $20-70 \mathrm{~kg} / \mathrm{cm}^{2}$ and $30-125 \mathrm{~kg} / \mathrm{cm}^{2}$ at CPT 2 respectively. The friction ratio ranges from $1.19-1.87$ (CPT 1) and $1.33-1.79$ (CPT 2). At CPT 1 the soil seems to be competent at a depths of between 0.2 and $1.0 \mathrm{~m}$. The Robertson [42] soil chart classification shows wide variation of zones 5 to 8 corresponding to clayey silt to silty clay, sandy silt to silty clay, silty sand to sandy silt and sand to silty sand respectively (Figure 9). The plots of cone resistance and sleeve resistance against depth (Figure 10) show high degree of heterogeneity in the upper $1.4 \mathrm{~m}$, with geological succession of clayey silt to silty clay $(0-0.2 \mathrm{~m})$, sandy silt to clayey silt $(0.2-0.6 \mathrm{~m})$, silty sand to sandy silt $(0.6-1.0 \mathrm{~m})$ and sand to silty sand (1.0-1.2 m) for CPT 1 , while for CPT 2 , three geologic layering were interpreted consisting of clayey silt to silty clay $(0-0.2 \mathrm{~m})$, sandy silt to clayey silt $(0.2-0.6 \mathrm{~m})$ and silty sand to sandy silt $(0.6-1.0 \mathrm{~m})$. 
Consequently in order to avoid clay mixed soil, a depth of $0.6 \mathrm{~m}$ would be appropriate as founding depth for design and construction of shallow foundation and bases. The analyzed soil samples at both locations (Tables 2 and 3) shows liquid limits of $20-42.3 \%$ (within recommended 50 $\%$ ), plastic limits of $18-22.1 \%$ (within recommended 30 $\%$ ), plasticity index of $9.2-24.26 \%$, and shrinkage limits of $0.5-8.2 \%$ (low/medium good soil quality). The natural moisture content ranges from 10.2 - $15.9 \%$ which is moderately low. The soil recorded no value for gravel, $\%$ sand varies from $62.1-93.8, \%$ silt is in between $5.2-22$, clay ranges from $0.2-16 \%$. Based on this result, the soil is generally silty sand which corroborates the geoelectric sections and CPT geologic section. The average clay content in the soil is less than $10 \%$. Consequently it is expected that such soil will undergo immediate/elastic settlement than consolidation settlement, since most silty (except plastic silt) and granular soil undergo total settlement even shortly after construction.

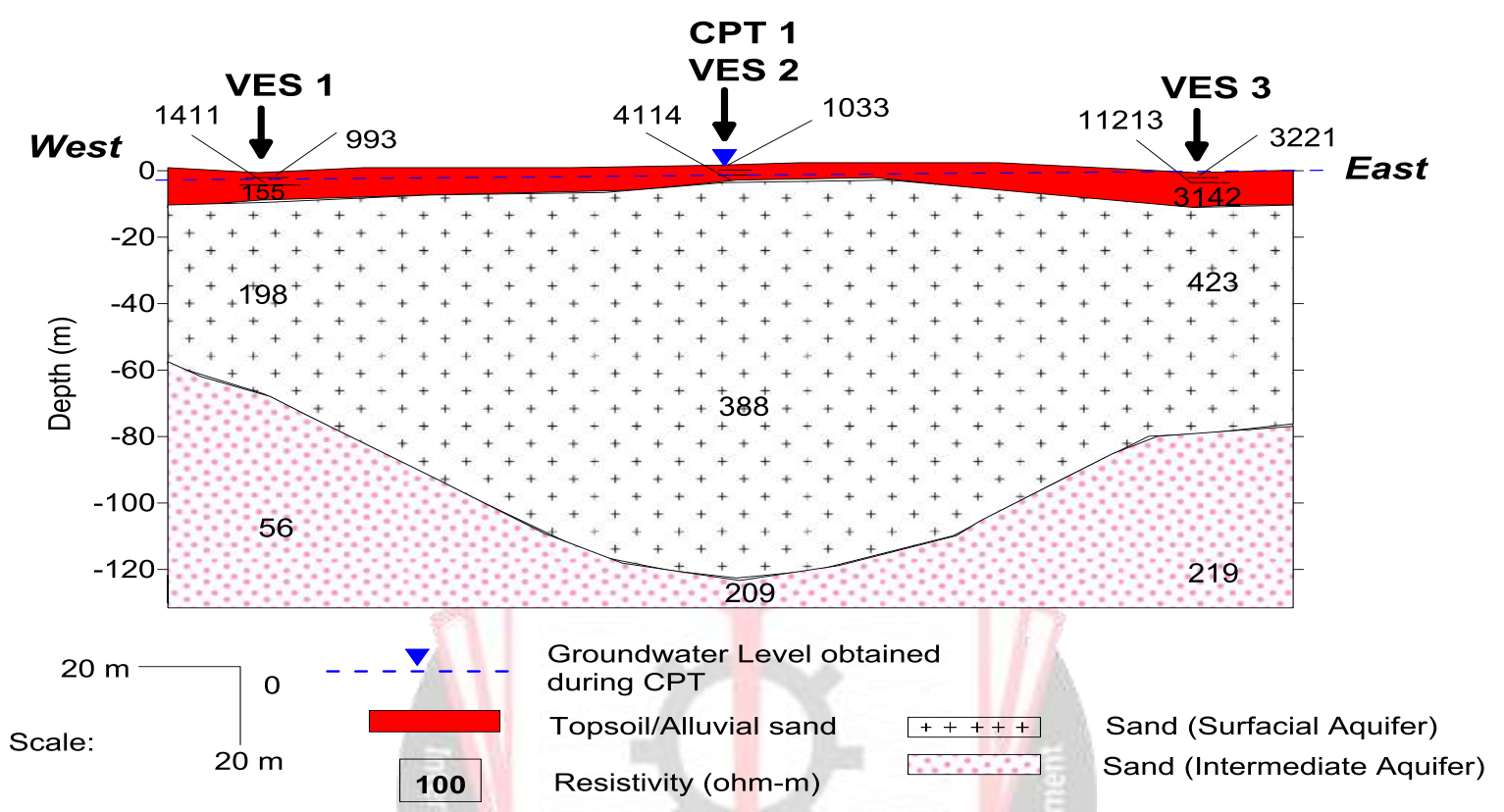

Figure 7: Geoelectric Section along Traverse 1 in Igbokoda also showing measured water level during the CPT
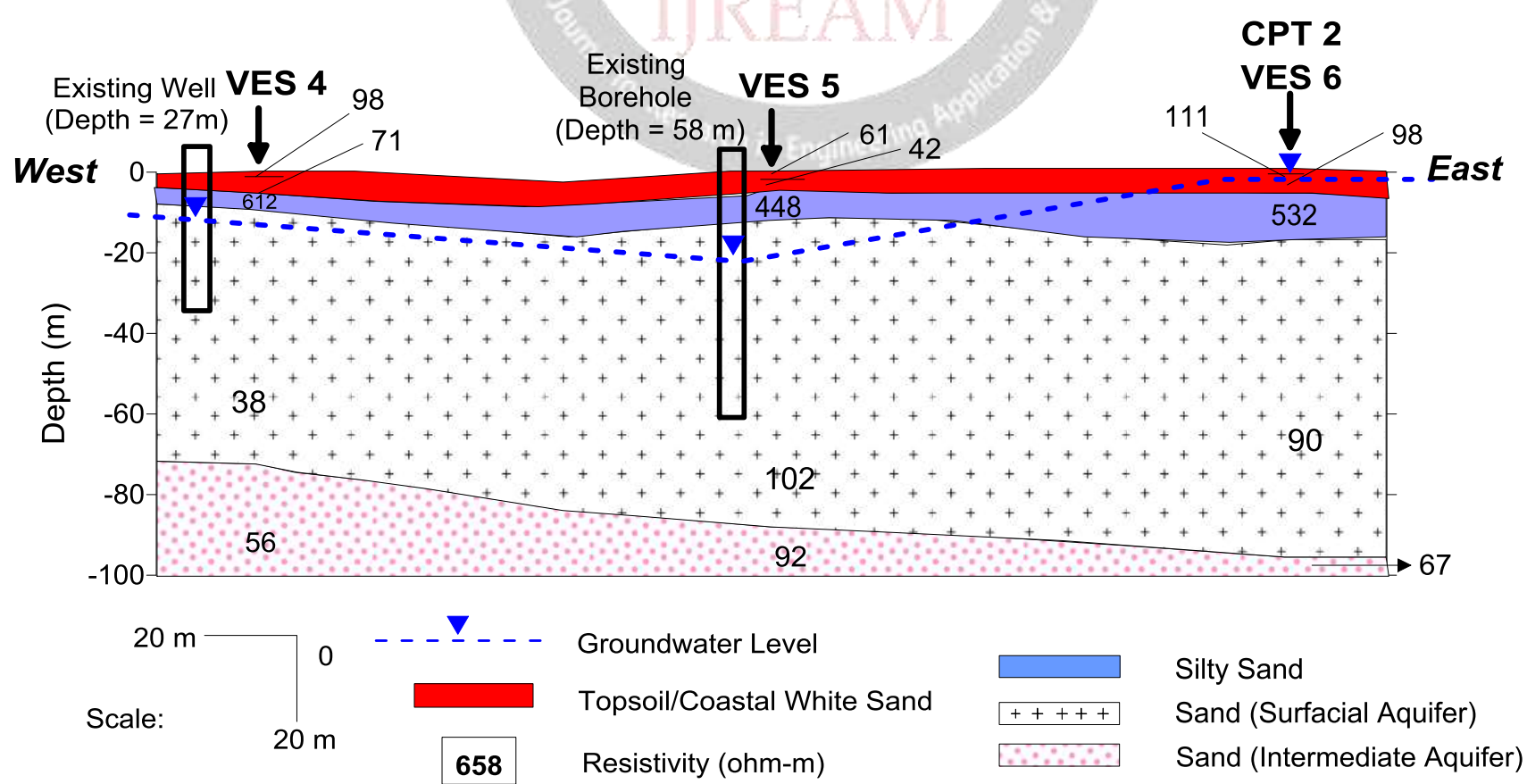

Figure 8: Geoelectric Section along Traverse 1 in Ugbonla/Ugbo and points of the existing wells with measured/inferred static water level 
Table 1: Geotechnical/Engineering Properties of Soil in Ojuala (Location 1)

\begin{tabular}{|c|c|c|c|c|c|c|c|c|c|c|c|c|c|}
\hline $\begin{array}{c}\text { Depth } \\
\text { (m) }\end{array}$ & $\begin{array}{c}\text { Cone } \\
\text { Resistanc } \\
\text { e }\end{array}$ & $\begin{array}{c}\text { Sleeve } \\
\text { Resistanc } \\
\mathrm{e}\end{array}$ & $\begin{array}{c}\text { Frictio } \\
\mathbf{n} \\
\text { Ratio }\end{array}$ & $\begin{array}{l}\text { L.L } \\
(\%)\end{array}$ & $\begin{array}{l}\text { P.L } \\
(\%)\end{array}$ & $\begin{array}{l}\text { P.I } \\
(\%)\end{array}$ & $\begin{array}{l}\text { S.L } \\
(\%)\end{array}$ & $\begin{array}{c}\text { M.C } \\
(\%)\end{array}$ & $\begin{array}{c}\% \\
\text { Grave } \\
1\end{array}$ & $\begin{array}{c}\% \\
\text { Sand }\end{array}$ & $\begin{array}{c}\% \\
\text { Silt }\end{array}$ & $\begin{array}{c}\% \\
\text { Clay }\end{array}$ & S.G \\
\hline 0.2 & 15 & 28 & 1.87 & 22.0 & - & - & 0.7 & 10.3 & - & 86.8 & 10.2 & 3.0 & 2.68 \\
\hline 0.4 & 25 & 35 & 1.40 & & & & & & & & & & \\
\hline 0.6 & 30 & 42 & 1.40 & 20 & - & - & 0.5 & 11.1 & - & 82.0 & 17.0 & 1.0 & 2.67 \\
\hline 0.8 & 55 & 68 & 1.24 & & & & & & & & & & \\
\hline 1.0 & 60 & 80 & 1.33 & 31.3 & 22.1 & 9.2 & 0.5 & 15.1 & - & 93.8 & 6.0 & 0.2 & 2.68 \\
\hline 1.2 & 80 & 95 & 1.19 & & & & & & & & & & \\
\hline 1.4 & 88 & 110 & 1.25 & 32.2 & 22.1 & 10.1 & 4.3 & 15.3 & - & 93.4 & 5.2 & 1.4 & 2.68 \\
\hline
\end{tabular}

Table 2: Geotechnical/Engineering Properties of Soil in Igbekebo (Location 2)

\begin{tabular}{|c|c|c|c|c|c|c|c|c|c|c|c|c|c|}
\hline $\begin{array}{c}\text { Depth } \\
\text { (m) }\end{array}$ & $\begin{array}{c}\text { Cone } \\
\text { Resistance }\end{array}$ & $\begin{array}{c}\text { Sleeve } \\
\text { Resistance }\end{array}$ & $\begin{array}{c}\text { Friction } \\
\text { Ratio }\end{array}$ & $\begin{array}{l}\text { L.L } \\
(\%)\end{array}$ & $\begin{array}{l}\text { P.L } \\
(\%)\end{array}$ & $\begin{array}{l}\text { P.I } \\
(\%)\end{array}$ & $\begin{array}{l}\text { S.L } \\
(\%)\end{array}$ & $\begin{array}{l}\text { M.C } \\
(\%)\end{array}$ & $\begin{array}{c}\% \\
\text { Gravel }\end{array}$ & $\begin{array}{c}\% \\
\text { Sand }\end{array}$ & $\begin{array}{c}\% \\
\text { Silt }\end{array}$ & $\begin{array}{c}\% \\
\text { Clay }\end{array}$ & S.G \\
\hline 0.2 & 20 & 30 & 1.50 & 42.3 & 18 & 24.26 & 8.2 & 15.9 & 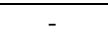 & 68.3 & 20.1 & 11.6 & 2.69 \\
\hline 0.4 & 30 & 40 & 1.33 & & & & & & & & & & \\
\hline 0.6 & 35 & 50 & 1.43 & 32 & 31.9 & 10.10 & 7.2 & 11.9 & - & 69.9 & 19.5 & 10.9 & 2.69 \\
\hline 0.8 & 55 & 80 & 1.45 & & & & & & & & & & \\
\hline 1.0 & 70 & 125 & 1.79 & 28 & 19.2 & 8.8 & 5.5 & 10.2 & - & 62.1 & 22.0 & 16.0 & 2.68 \\
\hline
\end{tabular}

The ultimate and allowable bearing capacity estimated from the cone resistance using Meyerhof [27] equation as presented in Table 3. The calculated bearing capacities could be used in determining the foundation type for structures [43]. The allowable bearing of the soil varies between 37 to $216 \mathrm{KN} / \mathrm{m}^{2}$ for CPT 1 , and $49-172 \mathrm{KN} / \mathrm{m}^{2}$ for CPT 2. Consequently an average allowable bearing capacity of $150 \mathrm{KN} / \mathrm{m}^{2}$ (ultimate bearing capacity of 450 $\mathrm{KN} / \mathrm{m}^{2}$ ) would be appropriate for design of shallow foundation in the area, at a depth not less than $1.0 \mathrm{~m}$.

The total settlement is the total compression of a saturated soil layer over a long period of time under static load. It is the combination of primary/elastic and secondary settlements. The rate of settlement depends on thickness of soil layer, permeability of soil, number of drainage faces, and magnitude of applied load. The commonly accepted basis of design is that the total settlement of a footing should be restricted to about $25 \mathrm{~mm}$ [44-45] as by so doing the differential settlement between adjacent footings is confined within limits that can be tolerated by a structure. The settlement analysis for foundation width of $0.5 \mathrm{~m}$ at three depth levels of $1 \mathrm{~m}, 2 \mathrm{~m}$ and $3 \mathrm{~m}$ produces relative high values (greater than $25 \mathrm{~mm}$ ) settlement values. But foundation width of $1.5-3$ m produces settlement less than $25 \mathrm{~mm}$ (Table 4). Although according to Meyerhof [27], Schmertamnn [28] total settlement limits of $60 \mathrm{~mm}$ (clay) and $50 \mathrm{~mm}$ (granular soil) are still tolerable. Therefore foundation width of $0.5 \mathrm{~m}$ for different depth levels is still within tolerable limit. However settlement at foundation is low when the foundation width is increase to $2 \mathrm{~m}$ and $3 \mathrm{~m}$. The calculation of bearing capacities for strip and square foundation is shown in Table 5. For strip foundation, the appropriate (recommended) ultimate bearing and allowable bearing capacity for depth levels of $0.6 \mathrm{~m}$ and $1.2 \mathrm{~m}$ are 1102 and $367 \mathrm{KN}$ and 2254 and $751 \mathrm{KN}$ respectively. The ultimate bearing and allowable bearing capacity for square foundation at depth levels of $0.6 \mathrm{~m}$ and $1.2 \mathrm{~m}$ are 1590 $2989 \mathrm{KN} / \mathrm{m}^{2}$ and $530-996 \mathrm{KN} / \mathrm{m}^{2}$ respectively.

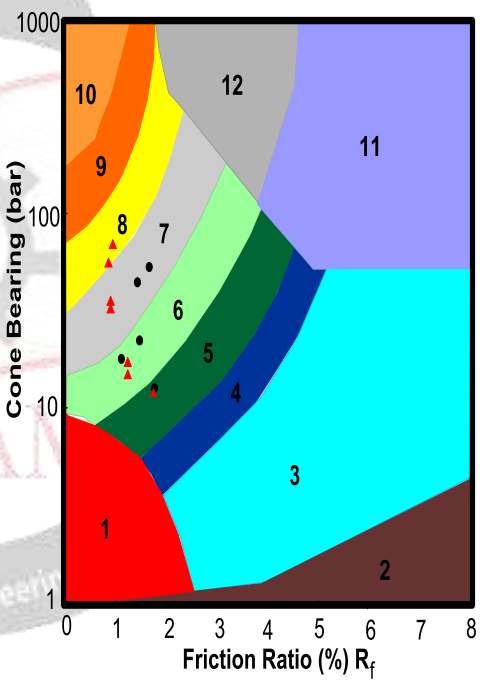

\begin{tabular}{|c|c|c|}
\hline Zone & $q_{c / N}$ & SBT \\
\hline 1 & 2 & Sensitive, fine grained \\
\hline 2 & 1 & Organic materials \\
\hline 3 & 1 & Clay \\
\hline 4 & 1.5 & Silty clay to clay \\
\hline 5 & 2 & Clayey silt to silty clay \\
\hline 6 & 2.5 & Sandy silt to clayey silt \\
\hline 7 & 3 & Silty sand to sandy silt \\
\hline 8 & 4 & Sand to silty sand \\
\hline 9 & 5 & Sand \\
\hline 10 & 6 & Gravelly sand to sand \\
\hline 11 & 1 & Very stiff fine grained ${ }^{*}$ \\
\hline 12 & 2 & Sand to clayey sand ${ }^{*}$ \\
\hline \multicolumn{3}{|c|}{ *Over consolidated or cemented } \\
\hline \multicolumn{3}{|c|}{$\triangle \mathrm{CPT}$ at Location 1} \\
\hline \multicolumn{3}{|c|}{ - CPT at Location 2} \\
\hline
\end{tabular}

Figure 9: Robertson's (1990) Soil Classification Chart and Description of Different Zones for soil in the two localities, with predominant Zones 6 and 7

An attempt was made to design for deep foundation at depth levels of $5 \mathrm{~m}, 10 \mathrm{~m}$, and $15 \mathrm{~m}$ for circular piles of $400 \mathrm{~mm}$, $500 \mathrm{~mm}$, and $600 \mathrm{~mm}$ while taking into consideration the groundwater level. The type of piles designed for in the area included driven/displacement piles and bored piles. The versatility and cost effectiveness are part of the governing factors considered. The bearing capacity of pile depends on pile diameter, founding depth, vertical stress, area of the pile, method of installation etc. The result shows that the larger the diameter of the pile, the better its bearing capacity. For driven pile at $5 \mathrm{~m}, 10 \mathrm{~m}$, and $15 \mathrm{~m}$, the adopted allowable capacity based on calculation is in between $64-115 \mathrm{KN}, 206-347 \mathrm{KN}$, and $418-677 \mathrm{KN}$ 
respectively.

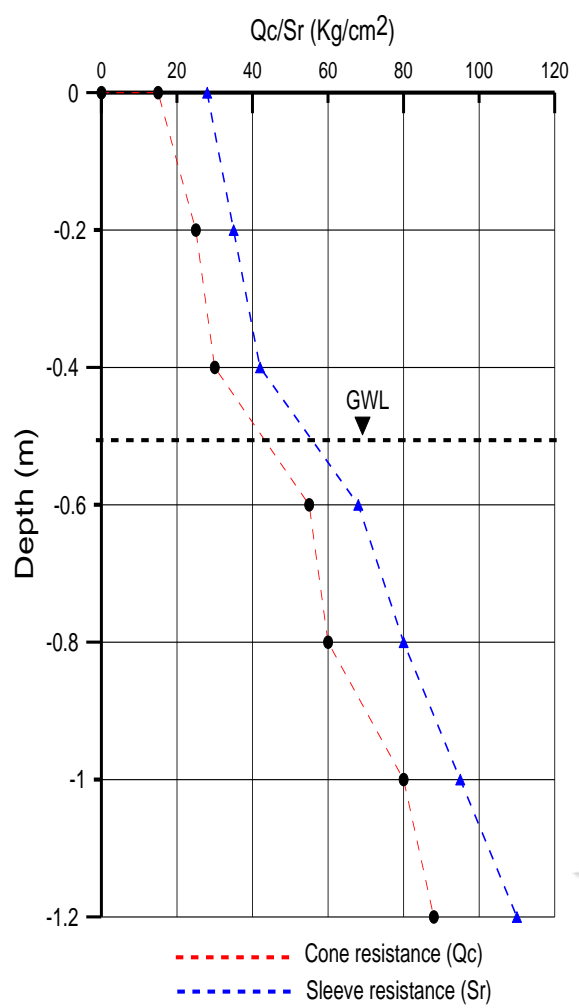

(a)
GEOLOGY

Clayey silt

to Silty clay

Sandy silt

to clayey

silt

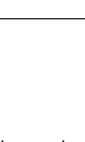

Silty sand to
Sandy silt

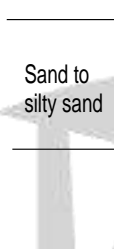

Sand to
silty sand

$t_{-1}$

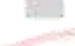

recommended that pile load test be conducted before the design, construction and installation of pile [46] in the locality to ensure this proposed design alternatives be effectively and correctly used in the study area.

Table 3: Bearing Capacities estimated from the Cone resistance values for both sites (locations)

\begin{tabular}{ccccc}
\hline \multirow{2}{*}{$\begin{array}{c}\text { Depth } \\
(\mathrm{m})\end{array}$} & \multicolumn{2}{c}{ CPT 1 } & \multicolumn{2}{c}{ CPT 2 } \\
\cline { 2 - 5 } & $\begin{array}{r}q_{\text {allowable }} \\
\left(\mathrm{KN} / \mathrm{m}^{2}\right)\end{array}$ & $\begin{array}{r}q_{\text {witimate }} \\
\left(\mathrm{KN} / \mathrm{m}^{2}\right)\end{array}$ & $\begin{array}{c}q_{\text {allowable }} \\
\left(\mathrm{KN} / \mathrm{m}^{2}\right)\end{array}$ & $\begin{array}{r}q_{\text {ultimate }} \\
\left(\mathrm{KN} / \mathrm{m}^{2}\right)\end{array}$ \\
\hline 0.2 & 37 & 110 & 49 & 147 \\
0.4 & 61 & 184 & 74 & 221 \\
0.6 & 74 & 221 & 86 & 257 \\
0.8 & 135 & 404 & 135 & 404 \\
1.0 & 147 & 441 & 172 & 515 \\
1.2 & 196 & 588 & - & - \\
1.4 & 216 & 647 & - & - \\
\hline
\end{tabular}

Table 4: Settlement variation at Different Depths and Foundation Widths

\begin{tabular}{llll}
\hline Foundation width & \multicolumn{3}{l}{ Settlement $(\mathrm{mm})$ at Depth Level $(\mathrm{m})$} \\
\cline { 2 - 4 }$(\mathrm{m})$ & $1 \mathrm{~m}$ & $2 \mathrm{~m}$ & $3 \mathrm{~m}$ \\
\hline 0.5 & 46.17 & 45.84 & 45.19 \\
1.0 & 30.28 & 31.00 & 31.10 \\
1.5 & 26.39 & 27.39 & 27.67 \\
2.0 & 16.27 & 17.72 & 18.34 \\
2.5 & 13.02 & 14.57 & 16.61 \\
3.0 & 10.88 & 12.50 & 14.58 \\
\hline
\end{tabular}

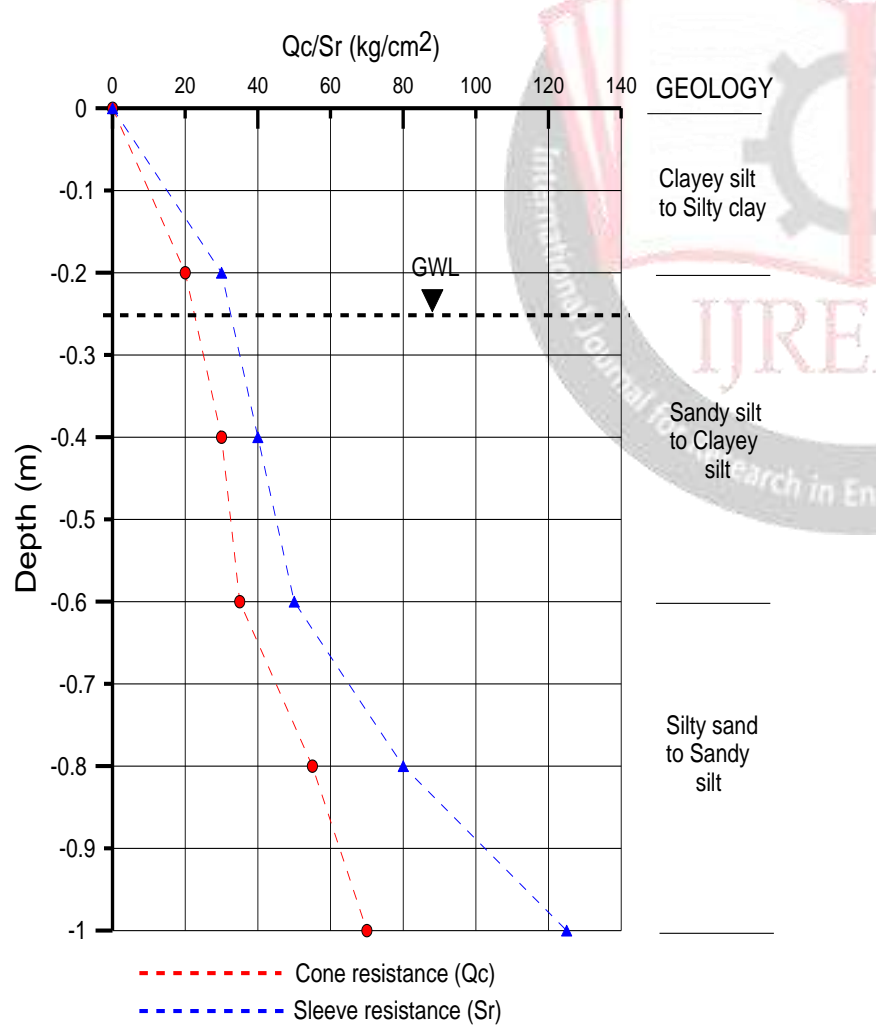

(b)

Figure 10: Plots of Cone resistance and sleeve resistance against depth at location 1 and 2, corresponding to (a) Ojuala CPT 1 (b) Igbekebo CPT 2

The allowable bearing capacity for bored piles ranges from $34-69 \mathrm{KN}, 85-165 \mathrm{KN}$, and $146-268$ at depth levels of $5 \mathrm{~m}, 10 \mathrm{~m}$, and $15 \mathrm{~m}$ respectively (Table 6). Although it is
Table 5: Bearing Capacities for Strip and Square Shallow Foundations in the Study area

\begin{tabular}{ccccc}
\hline \multirow{2}{*}{$\begin{array}{c}\text { Depth } \\
(\mathrm{m})\end{array}$} & Strip & Square & Strip & Square \\
\cline { 2 - 5 } & $\begin{array}{c}q_{\text {witimate }} \\
\left(\mathrm{KN} / \mathrm{m}^{2}\right)\end{array}$ & $\begin{array}{c}q_{\text {witimate }} \\
\left(\mathrm{KN} / \mathrm{m}^{2}\right)\end{array}$ & $\begin{array}{c}q_{\text {allowable }} \\
\left(\mathrm{KN} / \mathrm{m}^{2}\right)\end{array}$ & $\begin{array}{c}q_{\text {allowable }} \\
\left(\mathrm{KN} / \mathrm{m}^{2}\right)\end{array}$ \\
\hline 0.6 & 1102 & 1590 & 367 & 530 \\
1.2 & 2254 & 2989 & 751 & 996 \\
\hline & \multicolumn{5}{c}{} \\
& IV. CONCLUSION
\end{tabular}

Subsoil evaluation and foundation design in Ilaje area of Ondo State for civil engineering structure using geoelectrical and geotechnical methods of investigation were carried out. The investigation was to provide information on the stratigraphy, nature, structural disposition and competence of the subsoil. Six (6) Vertical Electrical Sounding (VES) stations were occupied and this was complemented with geotechnical analysis using CPT and seven soil samples collected at the CPT locations, within $1.4 \mathrm{~m}$ depth. All the determined geotechnical parameters of the subsoil fall within the specification recommended for foundation material. According to Robertson's chart, the distribution of the CPT data obtained encompasses four geologic zones and composed of clayey silt to silty clay, sandy silt to silty clay, silty sand to sandy silt and sand to silty sand respectively. The VES shows a predominant HKQ curve types which account for $66.67 \%$. The upper $5 \mathrm{~m}$ is characterized by moderate thickness and high resistivity values to sustain the structure. The topsoil (the upper $5 \mathrm{~m}$ ) has high resistivity and thickness values that 
can sustain structural foundation load. The average bearing capacity of $150 \mathrm{KN} / \mathrm{m}^{2}$ could be adopted in the area for design of bases/footings for shallow foundation at a depth not less than $1.0 \mathrm{~m}$. The total settlement is less than $50 \mathrm{~mm}$ tolerable limit for foundation width ranging from 0.5 to 3.0 $\mathrm{m}$. The allowable capacity of the driven pile ranges $64-$
$115 \mathrm{KN}, 206-347 \mathrm{KN}$, and $418-677 \mathrm{KN}$ at $5 \mathrm{~m}, 10 \mathrm{~m}$ and $15 \mathrm{~m}$ respectively. The allowable bearing capacity for bored piles ranges from $34-69 \mathrm{KN}, 85-165 \mathrm{KN}$, and $146-268$ at depth levels of $5 \mathrm{~m}, 10 \mathrm{~m}$, and $15 \mathrm{~m}$ respectively.

Table 6: Axial Pile Capacity for proposed Driven and Bored Piles

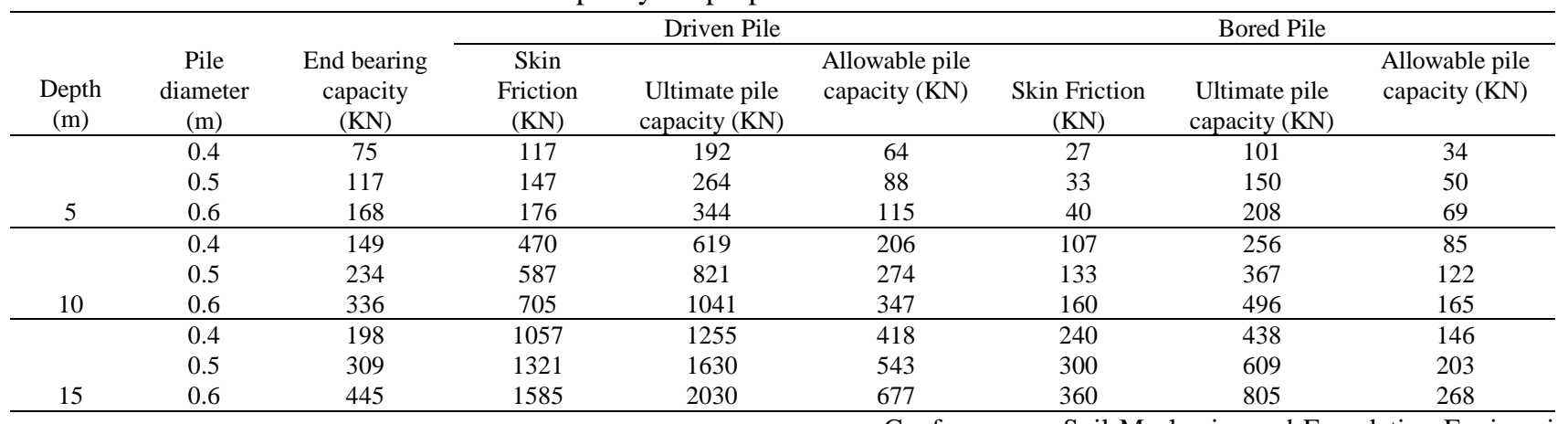

\section{ACKNOWLEDGMENT}

Special appreciation to TETFund, Nigeria through Centre for Research and Development of Rufus Giwa Polytechnic, Owo, Ondo State, Nigeria for providing the fund for this research work.

\section{REFERENCES}

[1] K. Terzaghi, and R. B. Peck, G. Mesri, "Soil Mechanics in Engineering Practice,” 3rd ed., John Wiley Sons Inc., 1996.

[2] M. Robert, “Avoiding Foundation Failures," second edition. John Willey publisher p 5-20. Tomlinson, M.J. (1980). Foundation design and construction, pp 37-55, 99, 265-327, 1996.

[3] Y. A. Fishman, "Effect of geological factors upon the pattern of failure and the stability of rock foundations of concrete dams," Bull. Int. Assoc. Eng. Geol. 20, 18, 1979. https://doi.org/10.1007/BF02591235.

[4] T. Lunne, and P. K. Robertson, J. J. M. Powell, "Cone penetration testing in Geotechnical Practice." Blackie Academic and Professiona, London, P. 312, 1997.

A. Eslami, and M. Gholami, "Bearing capacity analysis of shallow foundations from CPT Data." Proceedings of the 16th International Conference on Soil Mechanics and Geotechnical Engineering, Millpress Science Publishers/IOS Press. 2005-2006. doi:10.3233/978-1-61499-656-9-1463

[5] S. Eslaamizaad, and P. K. Robertson, "Cone penetration test to evaluate bearing capacity of foundations in sands," Proceeding of 49th Canadian Geotechnical Society, pp. 429438, 1996.

[6] J. L. Briaud, and R. M. Gibbens, "Behavior of five large spread footings on sand." Journal of Geotechnical and Geoenvironmental Engineering. ASCE, Vol. 125, No. 9, pp. 787-796, 1994.

[7] S. Amar, "Experimental study in full scale of shallow foundation behavior." Proceeding of 6th European
Conference on Soil Mechanics and Foundation Engineering, pp. 199-204, 1979.

[8] S. S. Gowd, "Electrical resistivity surveys to delineate ground water potential aquifers in Peddavanka water shed, Ananater pur Distict, Andhra prodesh India,” 2004.

[9] A. Neil, and I. Ahme, "A generalized protocol for selecting appropriate geophysical techniques," Dept. of Geol. and Geophs. University of Missouri-Rolla, Rolla, Missouri, pp. 19,2006

[10] E. P. Susan, "The role of Geophysics in 3-D mapping. Geology Survey Canada," ON, KIAOE8, Canada, pp. 61-65, 2004.

[11] M. O. Olorunfemi, and E. A. Mesida, "Engineering geophysics and its application in engineering site investigation - case study from Ile-Ife area." Nigerian Eng. $22,57-66,1987$

[12] K. Adebajo, "A Key-Note address by President of the Nigerian Institution of Structural Engineers," at the opening of a 3-day National Workshop on Collapse of Buildings and Engineering Structures. 9 Aug, 2005.

[13] A. A. Adepelumi, and M. O. Olorunfemi, "Engineering geological and geophysical investigation of the reclaimed Lekki Peninsula, Lagos, South West Nigeria;" Bulletin of Engineering Geology and the Environmental, pg 125-132, 2000 .

[14] K. F. Oyedele, S. Oladele, and C. N. Okoh, "Geo-assessment of subsurface conditions in Magodo brook estate, Lagos, Nigeria." International journal of advanced scientific technical research, 2(4) :733-741, 2012.

[15] K. F. Oyedele, S. Oladele, O. Adedoyin, "Application of geophysical and geotechnical methods to site characterization for construction purposes at Ikoyi, Lagos, Nigeria.” Journal of Earth sciences and geotechnical engineering, India, 1(1): 87-100, 2011

[16] M. P. Iloeje, “A new Geography of Nigeria." Longman Nigeria, 26-28, 1981. 
[17] G. O. Omosuyi, "Geophysical and Hydrogeological Investigations of Groundwater Prospects in the Southern Part of Ondo State, Nigeria." Ph.D Thesis, Department of Applied Geophysics, Federal University of Technology, Akure, Nigeria, 195pp, 2001.

[18] G. O. Omosuyi, J. S. Ojo, M. O. Olorunfemi, "Geoelectric Sounding to Delineate Shallow Aquifers in the Coastal Plain sands of Okitipupa Area, Southwestern Nigeria." The Pacific Journal of Science and Technology. 9 (2), $562-577,2008$.

[19] G. O. Omosuyi, J. S. Ojo, M. O. Olorunfemi, "Hydrochemical Investigation of Groundwater in Okitipupa area, Ondo State, Southwestern Nigeria." Journal of African Water Resources and Environment (Aquaterra). 1 (2), 3 - 13, 2007.

[20] M. E. Nton, Sedimentary and Geochemical Studies of Rock Units in the Eastern Dahomey Basin, Southwestern Nigeria. Unpublished Ph.D. Thesis, University of Ibadan, 315p, 2001.

[21] E. I. Enu, "Nature and Occurrence of Tarsands in Nigeria:" Ako, B.D., Enu, E.I. (Eds) Occurrence, Utilization and Economics of Tarsands. Nigeria Mining and Geosciences Society Publication on Tarsands Workshop. Olabisi Onabanjo University, Ago-Iwoye, 11-16, 1990.

[22] H. G. Billman, "Offshore Stratigraphy and Paleontology of the Dahomey Embayment, West African." NAPE Bulletin Vol. 7 (2) p121 - 130, 1992.

[23] M. E. Omatsola, O. S. Adegoke, "Tectonic evolution and Cretaceous stratigraphy of the Dahomey basin." Journal of Mining Geology, 18(1): 130-137, 1981.

[24] N. G. Obaje, "Geology and Mineral Resources of Nigeria." Published by Springer-Verlag Berlin Heidelberg. 221p, 2009.

[25] B. P. A. Vander-Velpen, "RESIST Version 1.0." M.Sc. Research Project. ITC: Delft Netherlands, 1988.

[26] G. G. Meyerhof, "Bearing capacity and settlement" ASCE, Journal of Geotechnical Engineering, Vol. 102, GT3, pp. 195 $-228,1976$.

[27] J. H. Schmertmann, "Guidelines for cone test, performance and design." Federal Highway Administration, Report FHWA-TS-78209, Washington, 145 p, 1978.

[28] British Standard Institutions, "Methods of Test for soils for Civil Engineering Purposes.” B.S 1377: Part 2, 1990. pp 8 200.

[29] J. H. Schmertmann, "Static Cone to Compute Static Settlement over Sand," Journal of the Soil Mechanics and Foundations Division. ASCE. Vol. 96. No. SM3. Proc. Paper 7302, pp. 101 1-1043, May, 1970.

[30] E. E. Debeer, "The scale effect in the transposition of the results of deep sounding tests on the ultimate bearing capacity of piles and caisson foundations." Geotechnique, Vol. 13, No. 1, pp.39-75, 1963.

[31] D. L. Webb, "Settlement of Structures on deep alluvial sand sediments in Durban, South Africa," British Geotechnical Society Conference on In-Situ Investigations in Soils and Rocks, Session III, paper 16, London, England, 13-15, pp. 133-140, May, 1969.
[32] A. Eslami, M. Gholami, "Bearing capacity of shallow foundations from CPT data," proceeding of 3rd Iranian International Conference on Geotechnical Engineering and Soil Mechanics, pp. 93-97, 2002.

[33] CFEM, "Canadian Foundation Engineering Manual." Third Ed, Canadian Geotechnical Society, BiTech. Publishers, Vancouver, 512 p, 1992.

[34] A. Eslami, B. H. Fellenius, "Pile capacity by direct CPT and CPTu methods applied to 102 case histories." Canadian Geotechnical Journal, Vol. 34, No. 6, pp. 880 - 898, 1997.

[35] J. deRuiter, F. L. Beringen, "Pile Foundations for Large North Sea Structures." Marine Geotechnology, Vol. 3, No. 3, pp. 267-314, 1979.

[36] M. Bustamante, L. Gianeeselli, "Pile Bearing Capacity Predictions by Means of Static Penetrometer CPT." Proceedings of the 2nd European Symposium on Penetration Testing, ESOPT-II, Amsterdam, Vol. 2, 1982, pp. 493-500.

[37] American Petroleum Institute (API), "Recommended practice for planning, designing and constructing fixed offshore platforms," 15th ed. API RP2A, 1984.

[38] M. T. Tumay, M. Fakhroo, "Friction Pile Capacity Prediction in Cohesive Soils Using Electric Quasi-Static Penetration Tests.” Interim Research Report No. 1, Louisiana Department of Transportation and Development, Research and Development Section, Baton Rouge, LA, 275 pp, 1982.

[39] N. Aoki, D. de Alencar, "An Approximate Method to Estimate the Bearing Capacity of Piles," Proceedings, the 5th Pan-American Conference of Soil Mechanics and Foundation Engineering, Buenos Aires, Vol. 1, 1975, pp. 367-376.

[40] J. E. Bowles, "Foundation Analysis and Design," McGrawHill, Inc., New York, 1982, p.816.

[41] P. K. Robertson, "Soil classification using the cone penetration test." Canadian Geotechnical Journal 27:151$158,1990$.

[42] A. W. Skempton, "The Bearing Capacity of Clays," Proceedings Building Research Congress, 1951, Vol. 1, pp. 180-189.

[43] F. G. Bell, "Engineering Geology.” Elsevier Ltd; 2007. ISBN: 978-81-312-1117-5

[44] J. B. Burland, M. C. Burbidge, "Settlement of foundations on sand and gravel," Proceedings of the Institution of Civil Engineers, Part 1, 1985, 78, Dec., 1325-1381, 1984.

[45] G. G. Meyerhof, "Shallow Foundations," Journal of the Soil Mechanics and Foundations Division, 1965. 